\title{
STINK BUGS (HETEROPTERA, PENTATOMIDAE) AND AN UNIQUE HOST PLANT IN THE BRAZILIAN SUBTROPICS
}

\author{
Antônio Ricardo Panizzi ${ }^{1}$ \\ Jocélia Grazia
}

\begin{abstract}
Stink bugs are seed/fruit sucking insects feeding on an array of host plants. Among them, an exotic tree called privet, Ligustrum lucidum Ait. (Oleaceae), is very common in the urban areas of the Brazilian subtropics, where it is utilized as food source and shelter for over a decem species of bugs, year round. The species composition, their performance and abundance on this host, and possible causes for this association are discussed and illustrated.
\end{abstract}

KEYWORDS. Ligustrum lucidum, privet, Pentatomini, association host, Brazilian subtropics.

\section{INTRODUCTION}

The phytophagous stink bugs belonging to the subfamily Pentatominae are, in general, polyphagous, feeding on both cultivated and uncultivated plants. For this reason, they are major pests of many important crops, such as legumes, cereals, and tree crops throughout the world; and wild hosts play an important role in the buildup of populations of pest species, particularly in the tropical regions where they are able to reproduce year round (PANIZZI, 1997).

Among the many perennial host plants of pentatomids, perhaps one of the most intriguing plant is a species of privet, Ligustrum lucidum Ait. (Oleaceae), a very common and abundant ornamental tree in southern Brazil. It is an exotic plant, originally from China, reaching $8-10 \mathrm{~m}$ high. During most of the year, in northern Paraná state, plants carry fruits (small round berries) which are very abundant especially on the outer surface of the plant. This gives to the plant a typical light-green coloration when fruits are immature, becoming darkish-purple at the time of fruit maturation. The flowers and all

1. Centro Nacional de Pesquisa de Soja, Empresa Brasileira de Pesquisa Agropecuária, Caixa Postal 231, 86001-970, Londrina, PR, Brasi (panizzi@cnpso.embrapa.br)

2. Departamento de Zoologia, Universidade Federal do Rio Grande do Sul, Av. Paulo Gama s/n, 90046-900, Porto Alegre, RS, Brasil (jocelia@vortex.ufrgs.br). 
stages of fruit development co-exist, which makes the plant to have reproductive structures year round. It is used as rootstock in grafting of olive, Olea europaea L., and is frequently misidentified with a very close privet species, Ligustrum japonicum Thunb.; this last species is shorter (3-6 m) and its fruits slightly more elongated (Milano, 1949, Joly, 1976).

Over several years we have observed great numbers of nymphs and adults of the cosmopolitan southern green stink bug, Nezara viridula (L., 1758) colonizing privet, $L$. lucidum in Londrina and in Curitiba, both in the State of Paraná, Brazil. Additional observations indicated the presence of several other species of pentatomids living on this plant in southern Brazil. Apparently, because it is a very conspicuous plant in time and space and, it provides abundant food resources during most of the year, stink bug species (endemic and exotic) have adapted to exploit this plant as a food resource. Biological aspects with regard to the performance of nymphs and adults of each species found on this plant, with comments on their developmental stages, and their seasonal phenology, will be presented. In addition, we discuss possible reasons to explain why this tree is being so intensively used as a host plant by pentatomid bugs, including pest and non pest species.

\section{MATERIAL AND METHODS}

The field study was conducted in Londrina (23 $\left.11^{\prime} \mathrm{S}, 51^{\circ} 11^{\prime} \mathrm{W}\right)$ from April 1996 to March 1997. Privet trees (fig. 8) were examined. The bugs were sampled weekly, using a sweep net. Each sample consisted of 10 strokes of the net against the plant foliage, repeated 30 times, on different plants. The bugs collected were put in plastic bags and taken to the laboratory. The number of nymphs and adults of each pentatomid species were recorded. After recording the number of bugs, they were killed by frozen and pinned, identified, and deposited in the Insect Collection of the Centro Nacional de Pesquisa de Soja, in Londrina, PR. The mean number of nymphs and adults/month was calculated.

Nymph and adult biologies were conducted from September 1996 to February 1997 in an environmental chamber maintained at $25 \pm 1^{\circ} \mathrm{C}, 65 \pm 5 \mathrm{RH}$, and a photoperiod of 14:10 (L:D). For nymphs, 40 individual of each of the following species were tested: $N$. viridula, P. macunaima, $P$. stictica, L. deducta, A. tripterus, and P. guildinii (eggs of this last species were collected from soybean plants). For the remaining species, no eggs were obtained to allow the nymphal study. Nymphs were put singly in a petri dish $(9.0 \times 1.5 \mathrm{~cm})$ with moistened filter paper and privet berries. Food and filter paper were changed every 2 days. Daily observations were made. Nymphal percentage mortality was calculated, based on the number of nymphs that reached adulthood.

For adults, a variable number of pairs (5 to 20) was formed, out of nymphs reared in the laboratory. The following species were tested: P. macunaima, P. stictica, and $L$. deducta. $N$. viridula adults were not tested because the data were already published (Panizzi et al., 1996). The remaining species were not studied because nymphs were obtained in low numbers. Each pair was put in plastic box $(12.0 \times 12.0 \times 3.8 \mathrm{~cm})$, with moistened filter paper and covered with a lid, and fed with privet berries. Daily observations were made, and the percentage of females reproducing, total fecundity, and percentage egg hatchability were calculated.

\section{RESULTS AND DISCUSSION}

During the observations, 13 species of phytophagous pentatomids were found to feed and, many of them, to reproduce on L. lucidum. Eggs, nymphs and adults of six species were collected on privet: Nezara viridula (L., 1758); Pallantia macunaima Grazia, 1980; Pellaea stictica (Dallas, 1851); Loxa deducta Walker, 1867; Acrosternum impicticorne (Stål, 1872); and Antiteuchus tripterus (Stål, 1787). 

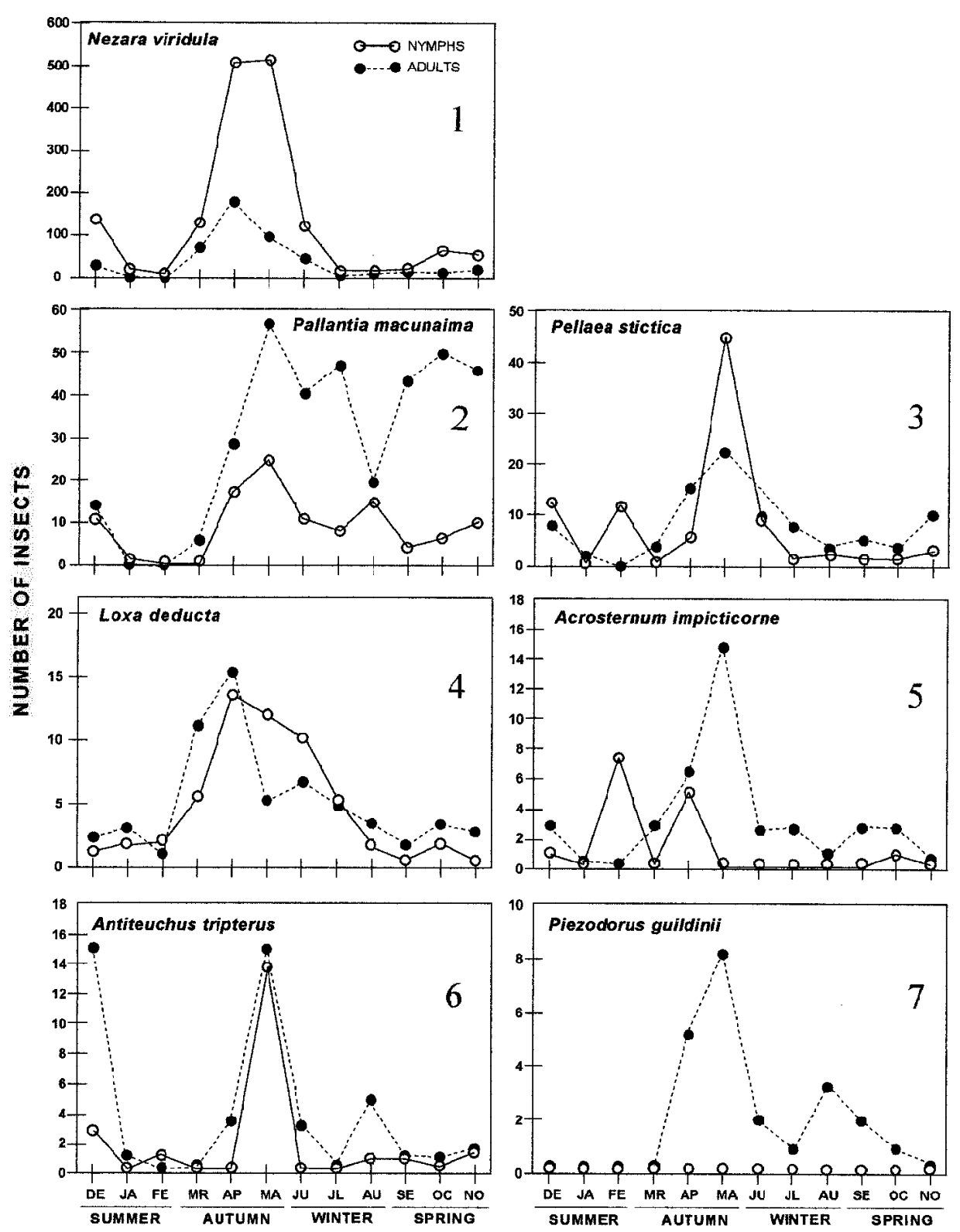

SE A S O N S

Figs. 1-7. Seasonal abundance of nymphs and adults of the most common pentatomids found on privet Ligustrum lucidum during a one-year period in northern Paraná state, Brazil. 


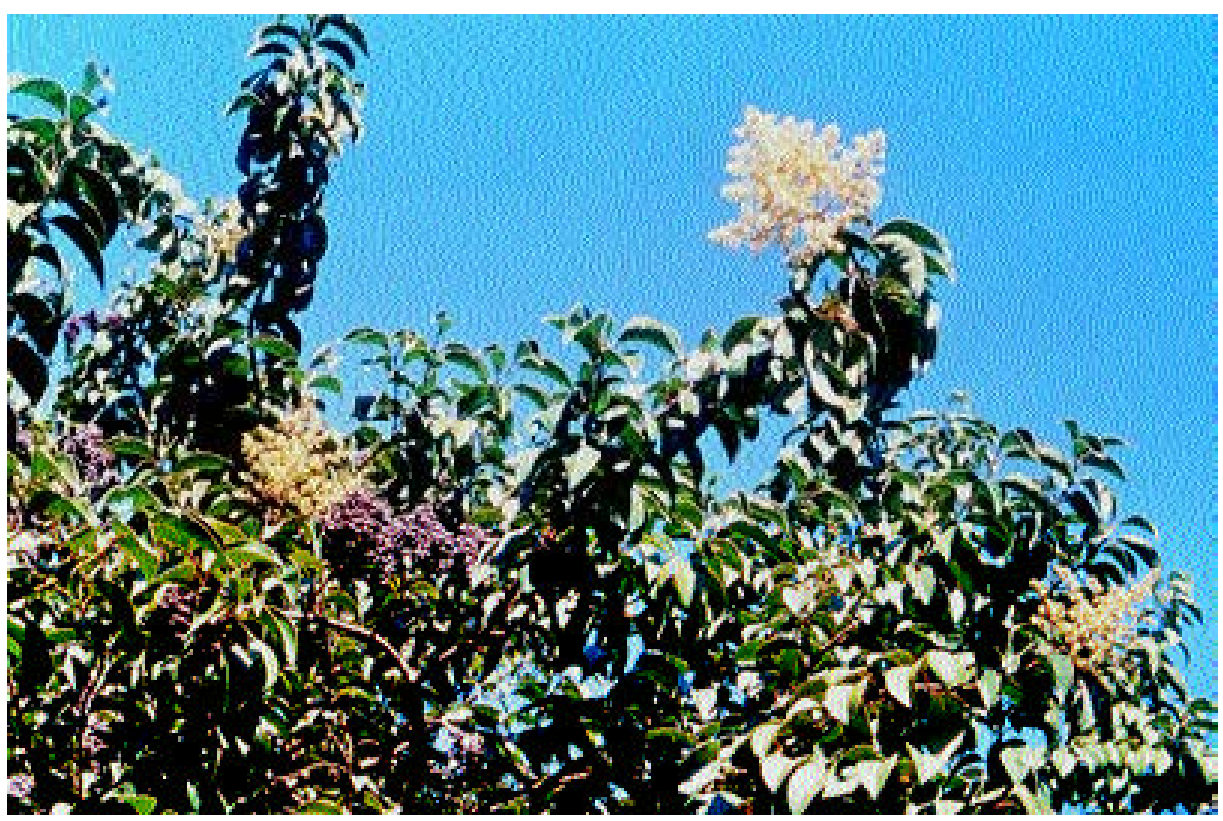

Fig. 8. Detailed view of privet tree Ligustrum lucidum showing branches with inflorescences (whitish) and fruits (berries) (purplish).

For the remaining seven species, only adults were collected: Piezodorus guildinii (Westwood, 1837); Antiteuchus mixtus (Fabricius, 1787); Euschistus heros (Fabricius, 1798); Dichelops (Diceraeus) melacanthus (Dallas, 1851); Thyanta perditor (Fabricius, 1794); Acrosternum runaspis (Dallas, 1851); and Euschistus (Lycipta) illotus Stål, 1860. We know of no other plant species which attract so many species of Pentatomidae. Some species were observed to be more abundant than others, particularly when plants were at the peak of the fruiting period. However, most of them were present on privet during the entire year.

Nezara viridula. The southern green stink bug is a cosmopolitan pentatomid, highly polyphagous, feeding on both cultivated and uncultivated plants. Because of this, and because it is a pest of many economic plants worldwide, it is probably the most studied pentatomid.

Among the species observed on privet, $N$. viridula was, by far, the most abundant (fig. 1). Nymphs and adults were present during most of the year, particularly from earlyautumn to early-winter (March-June). Apparently this occurred due to dispersion of the bugs from rural areas, where they colonize soybean, Glycine $\max (\mathrm{L}$.) Merrill, which is harvested late February-early March, to the urban areas, where privet trees are present at full fruiting stages at this time. Nymphs and adults were not recovered during JanuaryFebruary, when they were possibly concentrated on soybean, and July-September, when fruiting structures are less abundant, and the bugs look for alternate hosts or are present in low numbers.

Adults green, with segments of the antenna reddish (fig. 9). The median body length of females $18 \mathrm{~mm}(\mathrm{n}=10)$ and of males $14 \mathrm{~mm}(\mathrm{n}=10)$. 


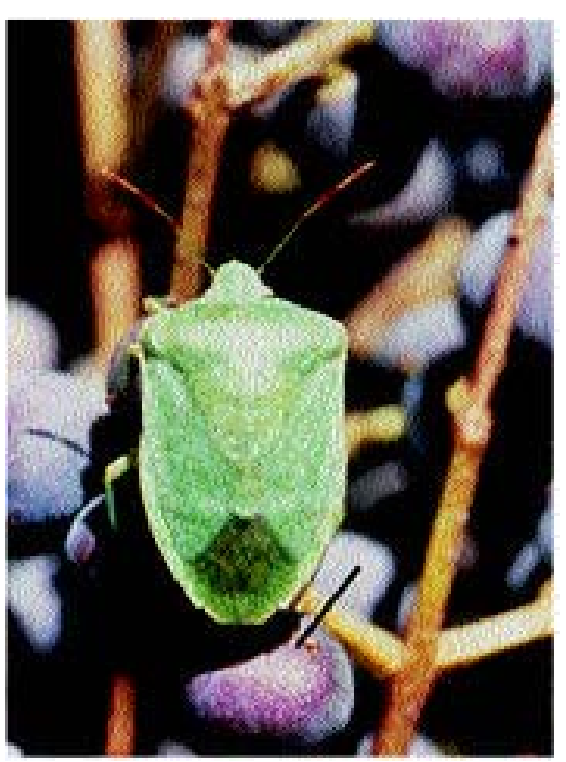

9

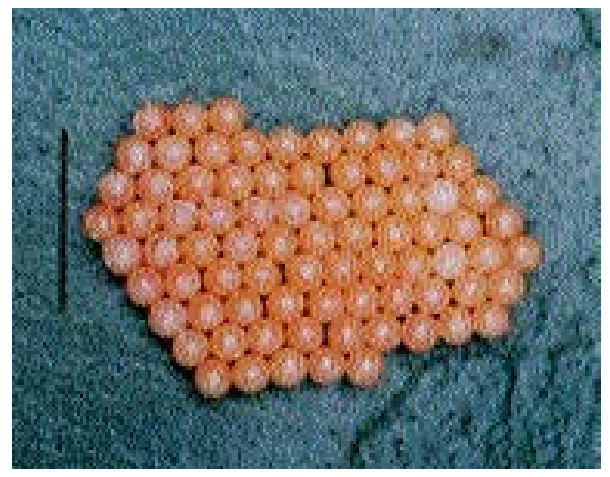

11

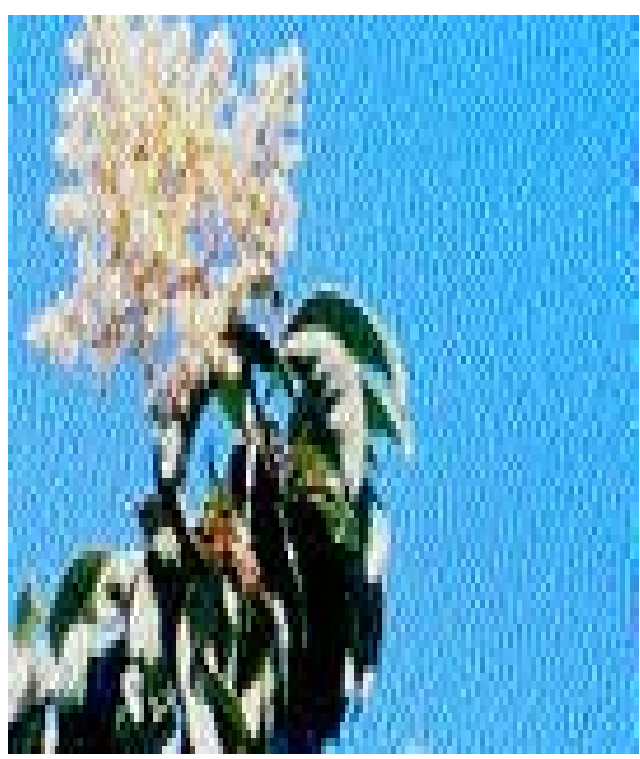

10

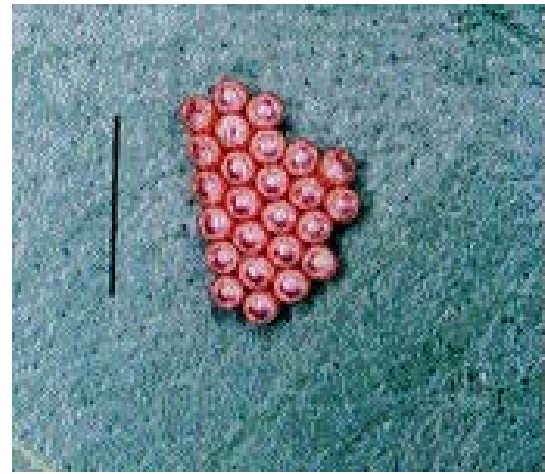

12

Figs. 9-12. Nezara viridula: 9, adult on mature fruits of privet; 10, fifth instar on a privet leaf; 11, egg masses on a privet leaf, early development; 12, egg masses, late development. (Scales: $2 \mathrm{~mm}$, fig. 9; $1 \mathrm{~mm}$, figs. 10-12). 
Nymphs predominantly green, but dark forms occur (fig. 10). Eggs light yellowishwhite (figs. 11, 12) or cream colored turning pinkish and reddish as embryo develops. In the laboratory, nymphs completed development on immature fruits of privet (mortality of $38.7 \%$ ), and adults show an excellent reproductive performance (PANIZZI et al., 1996), which is the reason why privet fruits are being used to mass rear this bug in the laboratory. This is reinforced by the fact that far more nymphs were captured than adults, because of the high rate of egg production by females.

Pallantia macunaima. Previous to this study, this neotropical pentatomid species, described by GRAZIA (1980) was considered somewhat rare, and its host plants unknown. However, it was the second most abundant species captured on privet trees. Like the previous species, nymphs and adults were present most of the year (fig. 2). More bugs were collected during autumn-winter (April-July), and spring-early summer (SeptemberDecember). Nymphs followed the population pattern, in general, but were less abundant than adults.

Adults (fig. 13) dorsal surface matte to dark brown with black punctures and reddish little maculae. Antennae and connexivum matte with black punctures on margins of segments. Median body length of females $9.0 \mathrm{~mm}(\mathrm{n}=10)$ and of males $7.5 \mathrm{~mm}(\mathrm{n}=10)$. Nymphs dorsally matte to dark brown. Head intensely punctured black and dark brown. Antennae matte, with black and yellowish rings. Antero-lateral margins of pronotum serrated, posterior margins rectilinear. Dorsal surface of the abdomen matte with ferrugineous to black punctures. Eggs light brown to greenish.

In the laboratory, in contrast to what was observed for $N$. viridula, most nymphs of P. macunaima did not complete their development on immature fruits of privet $(63.2 \%$ mortality). Adults (50\% of the females) reproduced, with a fecundity of $8.3 \pm 2.13 \mathrm{egg}$ masses and $41.7 \pm 12.30$ eggs/female, but egg hatchability was relatively low $(47.1 \pm 12.30$ $\%)$. These data suggest that privet fruits are only a reasonable food source, in spite of the bug's abundance on the plant. Perhaps, the insects feed on other parts of the plant or are too susceptible to handling in the laboratory, which may explain the present results. Unfortunately, no data on this bug biology is available to allow a comparison between its performance on privet with native host plants, which remain unknown.

Pellaea stictica. This was the third most abundant species. Like $N$. viridula, nymphs were observed in greater number than adults. Both, nymphs and adults, peaked during May at the end of autumn. Nymphs were also observed in greater numbers during the summer months (December and February) (fig. 3).

Adults (fig. 14) usually ferrugineous to black, with metallic green; dorsal surface with inumerous yellow maculae. Antennae black with metallic green. Legs black with dilated tibiae. Median body length of females $15.0 \mathrm{~mm}(\mathrm{n}=10)$ and of males $11.5 \mathrm{~mm}(\mathrm{n}=$ 10). Nymphs (fig. 15) easily recognized by the dark coloration and large size of abdominal plates; abdomen purple red between median and lateral plates, and dilation of the tibiae, specially in the 2nd to 4th instars. Eggs (fig. 16) light brown with a clear stripe.

In the laboratory, some nymphs were able to reach adulthood, but most $(82.5 \%)$ died before becoming adult. Because most nymphs died, only 5 pairs were formed and observed, and none reproduced when fed on fruits of privet. It is intriguing that present poor results on the nymph and adult biology of P. stictica contrasts with the field observations on the abundance of the bug on privet plants. Perhaps like P. macunaima, P. stictica complements its diet by feeding on other parts of the plant, and performs better 


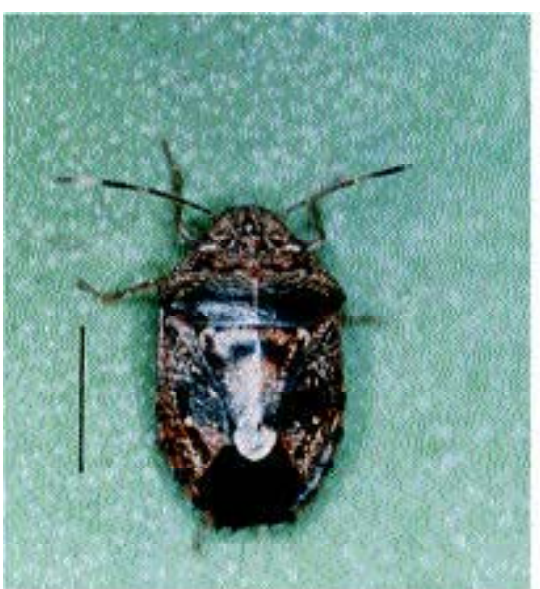

13 
in the field; or it may show also a high mortality and a low reproduction rate in the field, which did not prevent the species from being abundant. These data are supported by observations of BRAILOvSKY et al. (1992), who also found very difficult to raise P. stictica nymphs in the laboratory. They refer to the legume Senna papillosa (Britton \& Rose) Irwin \& Barneby as a host plant of this bug in Mexico. Young (1984) refers to another species of this legume Senna fructicosa (Mill) Irwin \& Barneby in Costa Rica, on which bugs were observed in great number.

Loxa deducta. This pentatomid was the fourth most abundant species. Equal numbers of nymphs and adults were captured throughout the year; both were more abundant from March to June (fig. 4).

Adults (fig. 17) green, with sharp pronotum spines. Median body length of females $18.0 \mathrm{~mm}(\mathrm{n}=10)$ and of males $16.0 \mathrm{~mm}(\mathrm{n}=10)$. Nymphs (fig. 18) ovoid, flat, greenyellowish, with reddish stripe along margins of head, thorax and abdomen. Black dots present on anterior margin of mesothorax and wing pads. Eggs (fig. 19) cream colored.

In the laboratory, survivorship of nymphs was high $(82.9 \%)$ when fed immature fruits of privet. Most females (83.3\%) oviposited, laying ca.18 egg masses or ca. 230 eggs each. L. deducta is known to feed and reproduce on soybean and on the other legumes Bauhinia candicans Benth. and Leucaena leucocephala (Lam.) de Wit. in Brazil (Link \& Grazia, 1987, PANizzi \& Rossi, 1991). On the last food plant, females had a fecundity of ca. 66 eggs/female. It is also reported to feed and reproduce on another species of privet, Ligustrum ovalifolium Hasskarl. in Rio Grande do Sul (LinK \& GRAZIA, 1987). Our studies with the privet species L. lucidum indicated a much better performance on this food plant compared to data in the literature when bugs were raised on other hosts, similar to what was observed on other pentatomid species such as $N$. viridula.

Acrosternum impicticorne. This pentatomid, along with Antiteuchus tripterus (Fabricius, 1787), was the fifth most abundant species recovered. Adults were captured in greater number than nymphs (fig. 5). Adults increased in numbers from March and peaked during May, decreasing thereafter. They were present on privet during most of the year, with numbers occurring during late spring and summer. Nymphs were captured in low numbers and only in October, December, February, and April. Because few nymphs (fig. 20 ) and adults were collected, no attempt was made to raise A. impicticorne in the laboratory. However, we suspect that nymphs will show some degree of development on privet berries, because they were observed feeding on these fruits in the field. A. impicticorne is known as a secondary pest of soybean in Brazil, and has been collected from several states such as Distrito Federal, Minas Gerais, São Paulo, Paraná, and Rio Grande do Sul (Grazia, Vecchio \& Hildebrand, 1982).

Adults dorsally green, with connexivum yellowish, and membrane of hemelytra infuscated. Median body length of females $14.0 \mathrm{~mm}(\mathrm{n}=10)$, and of males $12.0 \mathrm{~mm}(\mathrm{n}=10)$. Nymphs dark, with clear spots on dorsal surface of abdomen. Eggs brownish.

Antiteuchus tripterus. Nymphs and adults occurred in relatively low numbers on privet (fig. 6). Numbers of nymphs and adults peaked during May at late autumn, and adults also peaked in early summer (December).

Adults dorso-ventrally depressed, with dorsal surface testaceous to dark brown or black, densely punctured on pronotum and scutellum. Males usually darker than females. Median body length of females $12.0 \mathrm{~mm}(\mathrm{n}=10)$, and of males $11.0 \mathrm{~mm}(\mathrm{n}=10)$. Nymphs dark and flat. Eggs (fig. 23) clear colored. 


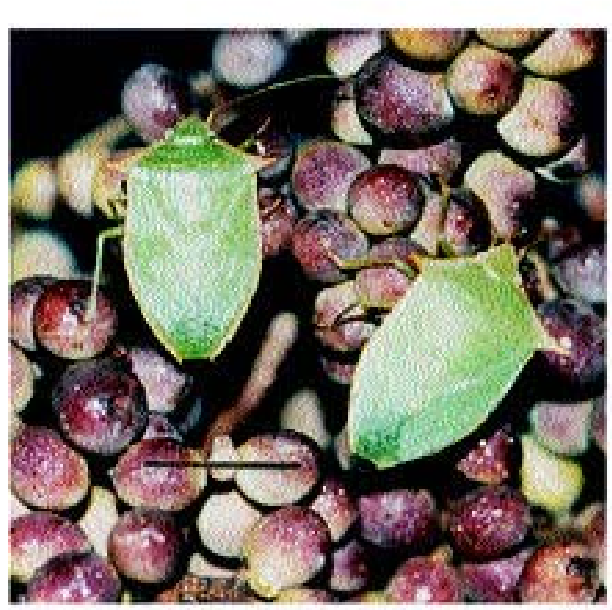

17

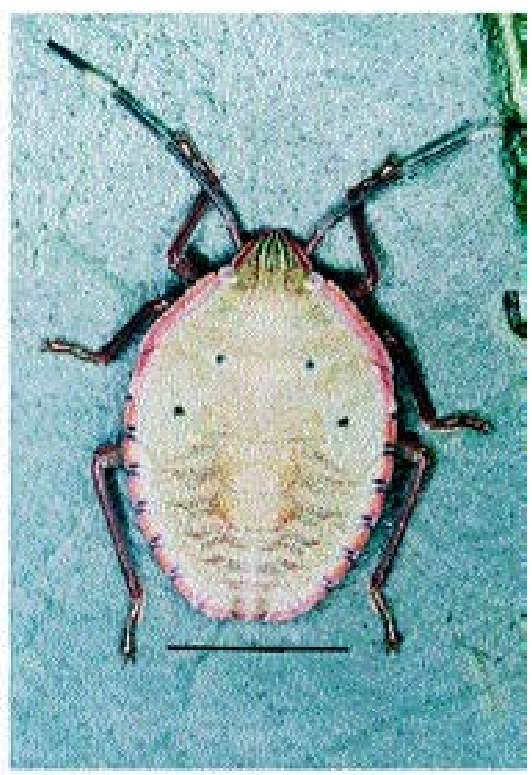

18

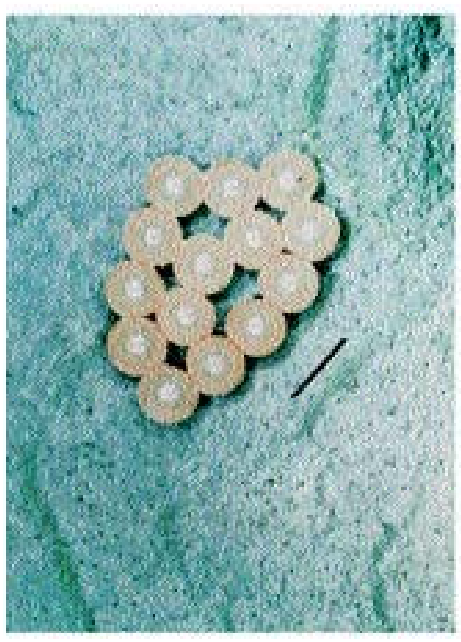

19

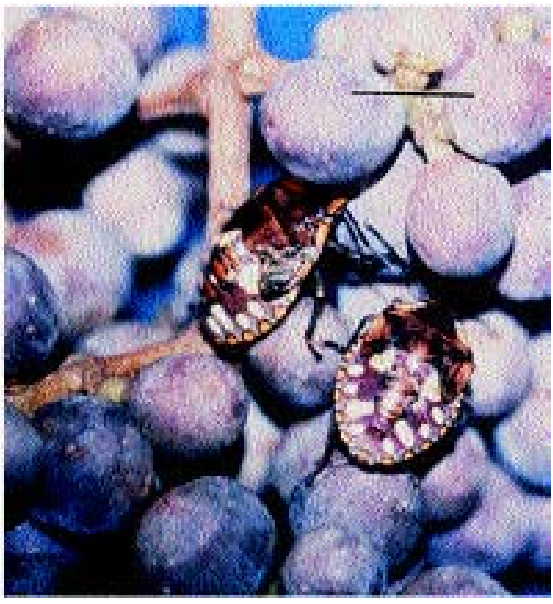

20

Figs. 17-20. Loxa deducta: 17, adults on fruits of privet; 18, fifth instar on a privet leaf; 19, egg mass on a privet leaf. 20, fifth instar of Acrosternum impicticorne on privet fruits. (Scales: $2 \mathrm{~mm}$, fig. 17; $1 \mathrm{~mm}$, figs. $18-19 ; 0,5 \mathrm{~mm}$, fig. 20 ). 
In the laboratory, no nymphs survived on privet berries. Although nymphs were recovered from privet fruits, they were also common on branches and on the tree trunk. We suspect that they feed to some degree on the branches and trunk, but this needs to be investigated further.

Antiteuchus tripterus is mentioned as a pest of cacao in several countries of South America and from the Caribbean islands (CALLAN, 1944; LozANO, 1955; LicERAS \& CASTRO, 1987). Maternal care in A. tripterus and its relationship to scelionid egg parasitoids have been studied by EBERHARDT (1975).

Piezodorus guildinii. Among the species that occurred in small numbers on privet, the small green stink bug $P$. guildinii was the most common. However, no nymphs and eggs were recorded, possibly indicating no reproduction. Adults were intercepted in greater numbers during April and May, decreasing thereafter. They were not recovered during late spring and summer months (November-February) (fig. 7). Probably the increase in adult populations during April and May was due to dispersion of bugs from areas where soybean was harvested. In a similar way, bugs were not find on privet during November-February because at that time they were colonizing soybean, one of their preferred hosts.

Adults light green to yellowish, with a red-band on the base of pronotum, particularly on females. Pronotum band, on males, brown-yellowish. Body length of females $11.0 \mathrm{~mm}(\mathrm{n}$ $=10)$, and of males $9.0 \mathrm{~mm}(\mathrm{n}=10)$. Early nymphs reddish-brown, and later instars yellowish. Eggs blackish, laid in two paralell rows (GALILEO et al., 1977; GrAZIA et al., 1980).

No nymphs and eggs were observed in the field, and when we tried to raise nymphs on privet fruits in the laboratory they all died. Although P. guildinii is a major pest of soybean in South America (PANIZZI \& SLANSKY, 1985), and is commonly found feeding and reproducing on wild legumes of the genus Indigofera (PANIzZI, 1992), it is difficult to maintain a colony of this bug in the laboratory on either of these host plants.

Antiteuchus mixtus. Specimens were recovered only occasionally, and only adults were intercepted. This species also is suspected not to reproduce on privet. Similar to $A$. tripterus, it feeds on cacao (CALLAN, 1944).

Adults oval, dorsally convex. Median body length of females $14 \mathrm{~mm}(\mathrm{n}=5)$, and of males $13 \mathrm{~mm}(\mathrm{n}=5)$. Color design variegated in females (fig. 21), and completely fuscous in males. Lighter forms sordid flavescent with ferrugineous to black punctures tending to form small clusters especially on hemelytra. Nymphs (female) have a black and white appearance (fig. 22); eggs were not recovered.

Euschistus heros. The brown stink bug was found very occasionally on privet plants. No nymphs or eggs were recovered, indicating the inability of bugs to reproduce on this plant. Laboratory attempts to raise nymphs on privet fruits failed. We suspect that, similar to other stink bug species, E. heros moves from preferred host plants, such as soybean, to privet, when soybean is harvested or when other wild and cultivated host plants are not available. Thus, privet is utilized only occasionally, more probably as shelter by E. heros. This bug is known to overwinter under dead leaves (PANIzZI \& Niva, 1994 ) and to accumulate lipids to pass the unfavorable season (PANIZZI \& Hirose, 1995).

Adults dark brown (summer type) with pronotum spines acute. Overwintering adults light brown (winter types) with pronotum spines more. Median body length of females $13.0 \mathrm{~mm}(\mathrm{n}=10)$, and of males $11.0 \mathrm{~mm}(\mathrm{n}=10)$. Early nymphs oval and light brown, becoming dark brown. Later instars yellowish (GraZIA et al., 1980). Eggs yellowish. 


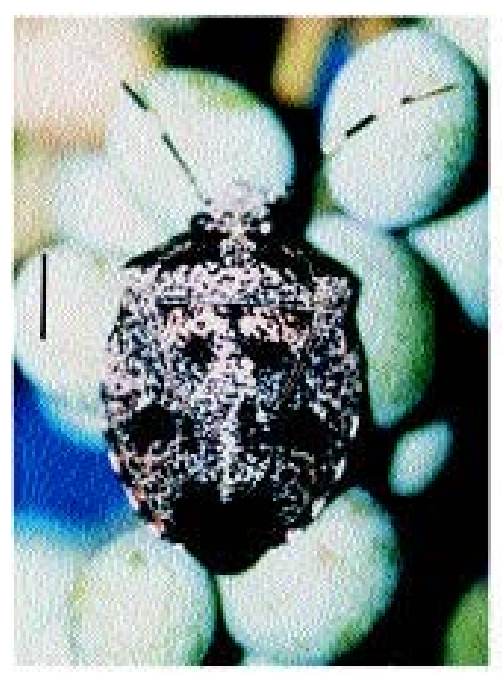

21

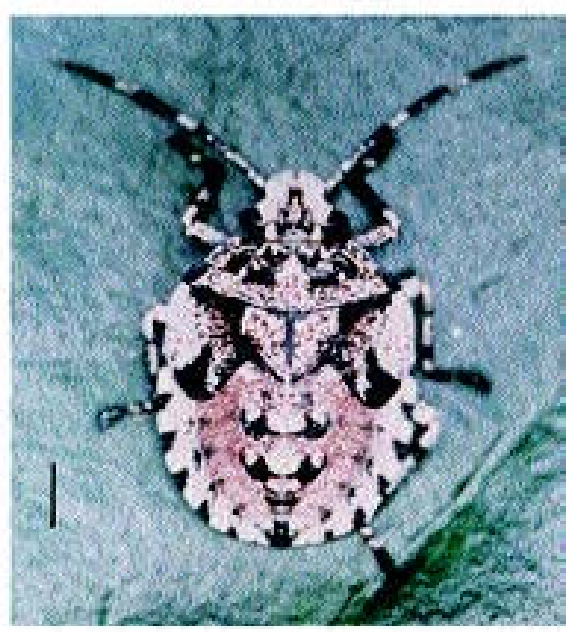

22

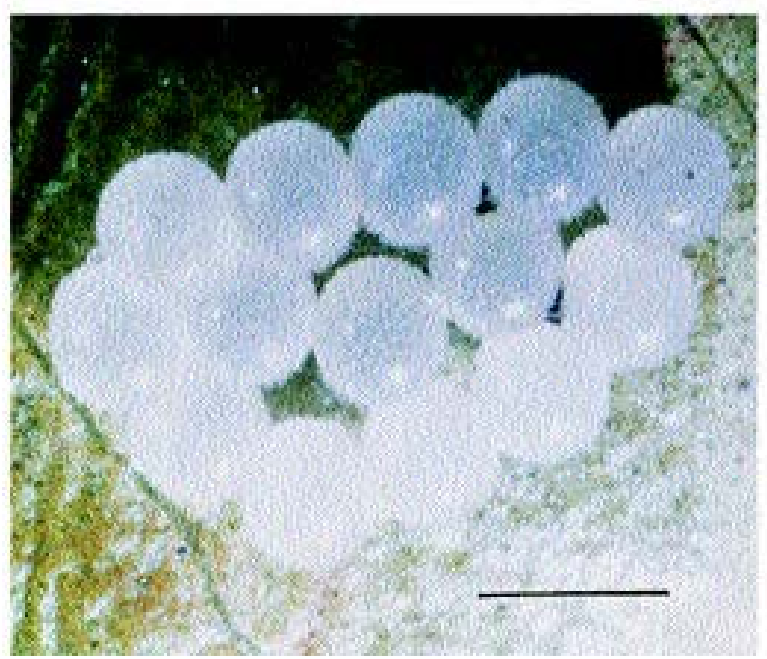

23

Fig. 21-23. Antiteuchus mixtus: 21, adult on fruits of privet; 22, fifth instar on a privet leaf; 23, egg mass of Antiteuchus tripterus on a privet leaf. (Scales: $3 \mathrm{~mm}$ ). 
Dichelops (Diceraeus) melacanthus. This neotropical species, very close to $D$. (D.) furcatus (Fabricius, 1775) was captured on very few occasions, and no nymphs or eggs were found on privet. Like other species, it is probably an occasional visitor of this tree. Adults brownish-green dorsally and green ventrally. Females $12.5 \mathrm{~mm}(\mathrm{n}=10)$ long, and males $11.0 \mathrm{~mm}(\mathrm{n}=10)$. Early instars brown and later instars brownish-green.

Dichelops melacanthus is reported to occur on soybean in Brazil (Corso, 1984). Ávila \& PANIZZI (1995) reported an unusual massive attack of D. melacanthus on seedling corn in the western State of Mato Grosso do Sul and in Paraná. The bugs feed on stems, causing yellowing of leaves and seedling death. It may also attack wheat plants. These attacks on corn and wheat occur in areas under no-tillage because adults, which feed on soybean, stay on the ground beneath crop residues after harvest and will feed on the following crop.

Thyanta perditor. Like the previous species, this pentatomid was also found in small numbers on privet. No nymphs and eggs were observed on this plant. This pentatomid inhabits much of northern South America (CALlan, 1948), but it seems to be more typical of West Indies and Mexico (Van Duzee, 1904). Waldbauer (1977) reported $T$. perditor as an important pest of soybean in Colombia. In Brazil, it also feeds on soybean, and on wheat, Bidens pilosa L. being its preferred wild host (PANIzZI \& Herzog, 1984).

Adults greenish with a red band on pronotum. Females $12.0 \mathrm{~mm}(\mathrm{n}=5)$ long, and males $11.0 \mathrm{~mm}(\mathrm{n}=5)$. Early instars oval and light brown to black. Later instars black with white or yellowish spots on abdomen (GRAZIA et al., 1982).

Acrosternum runaspis. Specimens were intercepted on privet on a very few occasions, and only as adults. Therefore we suspect it does not reproduce on privet. The species has a wide distribution in South America, like A. impicticorne, from Colombia to Argentina (Rolston, 1983). In Brazil it is reported from State of Rio Grande do Sul (LinK \& GRAZIA, 1987). This is the first record for Paraná.

Adults with dorsal surface of the body green and densely puncturated, with margins of head, thorax and abdomen orange yellow; legs green. Median body length of females $18.5 \mathrm{~mm}(\mathrm{n}=5)$, and of males $16.2 \mathrm{~mm}(\mathrm{n}=5)$. No nymphs and eggs were observed on privet plants.

Euschistus (Lycipta) illotus. Like the previous species, this pentatomid was intercepted on privet on a very few occasions, and only as adults and probably does not reproduce on privet. The species was described from Rio de Janeiro, Brazil; is known in South America from Bolivia to Paraguay and Argentina. In Brazil, it was collected also in the states of Mato Grosso, Espírito Santo, São Paulo, and Santa Catarina (Rolston, 1982). This is the first record for Paraná.

Remarks. The association of these 13 species of pentatomids (there are probably more, because we took the samples from only one place), with Ligustrum lucidum Ait. (Oleaceae) in the Brazilian subtropics is not surprising. Several factors involving the life history of pentatomids and characteristics of this plant make this association an unique case of a feeding guild (seed/fruit suckers) becoming adapted to a plant. The following may explain, at least in part, this interaction: 1) L. lucidum is perennial and very abundant, and thus continuously available to the bugs. Although it is an exotic plant in Brazil, it has adapted perfectly to the weather conditions in the subtropics, and also occurs in the more temperate zones in southern Brazil and Argentina. We did not find any records of when privet was introduced especifically in the Londrina, and Curitiba areas. Londrina was 
founded 67 years ago, and we may say that probably the trees are present in this area no longer than this period. Usually, privet is found in urban areas, in sidewalks as ornamental trees to provide shadow, or in streets used as contour lines. 2) This privet tree carries fruits during most of the year and, in some cases, flowers and immature and mature fruits occur on the same plant at the same time. The indeterminate growing habit of privet provides bugs with an abundance of different foods year round. So specialists on green fruit, specialists on semi-ripe fruit, and specialists on ripe fruit (and the same for the seeds) can all co-exist. This does not occur on other plant species with determinate growing habit, where these specialists must follow one another. 3) The privet offers an undisturbed ecological habitat, serving not only as a food resource for the bugs, but as shelter as well. Although the trees are mostly located in urban areas, where they are grown as ornamentals, they are not subjected to major disturbances, as occur with trees in rural areas, which are more likely to be destroyed to increase the amount of land for agriculture or cattle raising. 4) The architecture of the fruiting structures, probably facilitates feeding and provides protection from predators and parasites. In most cases bugs were found in between the berries, feeding or not. Apparently this niche provided by the fruits attract them to the outer surface of the plant where they are more frequently found. 5) The color of immature fruits (green) makes the stink bug species which are green, such as $N$. viridula, L. deducta, A. impicticorne, A. runaspis, and T. perditor, very mimetic, and, therefore, more difficult to be found by natural enemies.

Apparently this association of pentatomids with privet is of great advantage to the bugs. At least $50 \%$ of the species found reproduce on privet during several months of the year. The ones that apparently do not reproduce, use the plant as shelter or as a food source to sustain them when preferred hosts are scarce. There are no studies on the impact of the bugs' feeding on the plant's fitness. Apparently the bugs cause fruits to drop (several fruits on the ground were found with flanges, which indicates feeding activity by bugs), but additional studies are needed to clarify this point.

These results demonstrate that several species of pentatomids (endemic or not) inhabit privet trees in the northern area of Paraná, in Brazil. Soybean is an important crop in this area, and many of the stink bug species are also found on this crop. Of the 13 species found on privet, 7 species are known to feed on soybean (Panizzi \& Slansky, 1985). Soybean was introduced in northern Paraná in the late 1960's, and spreaded out fast. This increased the abundance of the pentatomids, which were already in the area on different host plants. Therefore, it seems that the bugs are moving from this legume to an oleaceous plant. They probably occur in other areas as well, where privet is present, from the more northern states of Minas Gerais in central Brazil, south to Rio Grande do Sul, and much probably further south in Uruguay and Argentina, in higher latitudes. However, additional surveys are needed to confirm this.

It is interesting to point that, for those species that reproduced on privet, their performance were much better than that observed on other host plants, such as soybean. Again, this also deserves further study, to explain which nutritional characteristics (e.g., nitrogen or other nutrients presence and/or absence of toxic allelochemicals) or physical attributes (such as fruiting architecture) of the privet fruits influence, and to what degree, the reproductive performance of the bugs. These, and other questions should be answered in order to explain the interaction of this group of pentatomids with this exotic tree in the Brazilian subtropics. 
Acknowledgments. To C. W. Schaefer, A. J. Cattelan, and C. B. Hoffman-Campo for suggestions on an early draft of the manuscript. To Émerson D. M. Oliveira, Jovenil J. da Silva, and Angélica F. Silva for their assistance. Contribution 09/99 of the Embrapa Soja; Contribution 352 of the Departamento de Zoologia, Universidade Federal do Rio Grande do Sul.

\section{REFERENCES}

Ávila, C. J. \& Panizzi, A. R. 1995. Occurrence and damage by Dichelops (Neodichelops) melacanthus (Dallas) (Heteroptera: Pentatomidae) in corn. Anais Soc. ent. Brasil, Londrina, 24 (1):193-194.

Brailovsky, H.; Cervantes, L. \& Mayorga, C. 1992. Hemiptera: Heteroptera de México XILIV Biología, estadios ninfales y fenología de la tribu Pentatomini (Pentatomidae) en la Estación de Biología Tropical «Los Tuxtlas,» Vera Cruz. México, D.F., Universidad Nacional Autónoma de México, Instituto de Biologia. 204 p. (Publicaciones especiales 8)

Callan, E. 1944. Cacao stink-bugs (Hem., Pentatomidae) in Trinidad, B. W. I. Revue Ent., Caen, 15 (3):321-324

1948. The Pentatomidae, Cydnidae and Scutelleridae of Trinidad. B. W. I. Proc. R. ent. Soc. Lond. (B), London, 17: 115-124.

Corso, I. C. 1984. Constatação do agente causal da mancha-de-levedura em percevejos que atacam a soja no Paraná. In: Seminário Nacional de Pesquisa de Soja, 3, Anais... Campinas, EMBRAPA. p. 152157

EBERHARDT, W. G. 1975. The ecology and behavior of a subsocial pentatomid bug and two scelionid wasps: strategy and counterstrategy in a host and its parasites. Smithson. Contr. Zool., Washington, 205:1-39.

Galileo, M. H. M.; Gastal, H. A. O. \& Grazia, J. 1977. Levantamento populacional de Pentatomidae (Hemiptera) em cultura de soja (Glycine $\max$ (L.) Merr.) no município de Guaíba, Rio Grande do Sul. Revta bras. Biol., Rio de Janeiro, 37(2):111-120.

Grazia, J. 1980. Revisão do gênero Pallantia Stål, 1862 (Heteroptera, Pentatomidae). Revta bras. Ent., São Paulo, 24(1):15-27.

Grazia, J.; Vecchio, M. C. Del et al. 1980. Estudo das ninfas de pentatomídeos (Heteroptera) que vivem sobre soja (Glycine max (L.) Merrill): I - Euschistus heros (Fabricius, 1798) e Piezodorus guildinii (Westwood, 1837). Anais Soc. ent. Brasil, Jaboticabal, 9(1):39-51.

1982. Estudo das ninfas de pentatomídeos (Heteroptera) que vivem sobre soja (Glycine max (L.) Merrill): III - Thyanta perditor (Fabricius, 1794). Anais Soc. ent. Brasil, Porto Alegre, 11(1): $139-146$

Grazia, J.; Vecchio, M. C. del \& Hildebrand, R. 1982. Estudo das ninfas de pentatomídeos (Heteroptera) que vivem sobre soja (Glycine max (L.) Merrill): IV - Acrosternum impicticorne (Stål, 1872). Anais Soc. ent. Brasil, Jaboticabal, 11(2):261-268.

JoLY, A. B. 1976. Botânica - Introdução à taxonomia vegetal. 3. ed. São Paulo, Nacional. 777 p.

Liceras, L. \& Castro, G. 1987. Antiteuchus tripterus (Fabricius) (Hemiptera, Pentatomidae) plaga nueva del cacaotero. Revta peru. Ent., Lima, 30(2):105.

Link, D. \& Grazia, J. 1987. Pentatomídeos da região central do Rio Grande do Sul. Anais Soc. ent. Brasil, Porto Alegre, 16(1):115-129.

Lozano, R. S. 1955. Biologia del Mecistorhinus tripterus F. (Hem., Pentatomidae) y su posible influencia en la transmision de la moniliasis del cacao. Cacao Colomb., Bogotá, 4: 15-42.

Milano, V. A. 1949. Las especies del genero «Ligustrum» cultivadas en la Argentina. Revta Invest. Agric., Buenos Aires, 3(3): 353-380

PanizzI, A. R. 1992. Performance of Piezodorus guildinii on four species of Indigofera legumes. Entomologia exp. appl., Amsterdan, 63(3): 221-228.

1997. Wild hosts of pentatomids: ecological significance and role in their pest status on crops. A. Rev. Ent., Stanford, 42:99-122.

Panizzi, A. R., \& Herzog, D. C. 1984. Biology of Thyanta perditor. Ann. ent. Soc. Am., Washington, 77(6):646650.

Panizzi, A. R. \& Hirose, E. 1995. Seasonal body weight, lipid content, and impact of starvation and water stress on adult survivorship and longevity of Nezara viridula and Euschistus heros. Entomologia exp. appl., Amsterdan, 76(3):247-253. 
Panizzi, A. R. \& Niva, C. C. 1994. Overwintering strategy of the brown stink bug in northern Paraná. Pesq. Agropec. Bras., Brasília, 29(3):509-511.

Panizzi, A. R. \& Rossi, C. E. 1991. Efeito da vagem e da semente de Leucaena e da vagem de soja no desenvolvimento de ninfas e adultos de Loxa deducta (Hemiptera: Pentatomidae). Revta bras. Biol., Rio de Janeiro, 51(3):607-613.

Panizzi, A. R. \& Slansky, F., JR. 1985. Review of phytophagous pentatomids associated with soybean in the Americas. Fla Ent., Gainesville, 68(1):184-214.

Panizzi, A. R.; Vivan, L. M. et al. 1996. Performance of the southern green stink bug (Heteroptera: Pentatomidae) nymphs and adults on a novel food plant (Japanese privet) and other hosts. Ann. ent. Soc. Am., Washington, 89(6):822-827.

Rolston, L. H. 1982. A revision of Euschistus Dallas subgenus Lycipta Stal (Hemiptera: Pentatomidae). Proc. ent. Soc. Wash., Washington, 84(2):281-296.

1983. A revision of the genus Acrosternum Fieber, subgenus Chinavia Orian, in the Western Hemisphere (Hemiptera: Pentatomidae). JI N. Y. ent. Soc., New York, 91(2):97-176.

Van DuzeE, E. P. 1904. Annotated list of the Pentatomidae recorded from America North of Mexico, with descriptions of some new species. Trans. Am. ent. Soc., Washington, 30:1-80.

Waldbauer, G. P. 1977. Damage to soybean seeds by South American stink bugs. Anais Soc. ent. Brasil, Jaboticabal, 6(2):223-229.

Young, A. M. 1984. Phenological patterns in reproduction in Senna fructicosa (Mill.) Irwin \& Barneby (Caesalpinaceae) and pod associate Pellaea sticta (Dallas) (Heteroptera: Pentatomidae) in Costa Rican tropical rain forest. J. Kans. ent. Soc., 57(4):413-422.

Recebido em 07.06.1999; aceito em 31.03.2000. 